\title{
Fluorescent Disulfide-functional Coordination Polymers for Sensitive Detection of Hydrogen Peroxide
}

\author{
Ya-Bo HaO, ${ }^{*}$ Dong Yuan, ${ }^{* *}$ Yu-Xiang Chang, ${ }^{* *}$ Wen-Jun Song, ${ }^{* \dagger}$ and Huai-Song WAng ${ }^{* * \dagger}$ \\ *Tianjin Key Laboratory of Food Biotechnology, Tianjin University of Commerce, Tianjin 300134, China \\ **Key Laboratory of Drug Quality Control and Pharmacovigilance, China Pharmaceutical University, \\ Ministry of Education, Nanjing 210009, China
}

\begin{abstract}
A new type of fluorescent coordination polymer $\left(\mathrm{NCP}_{\mathrm{Cd}}\right)$ based on disulfide carboxylate ligand was prepared by using one-pot synthesis for sensitive detection of reactive oxygen species (ROS). With the reaction between $\mathrm{NCP}_{\mathrm{Cd}}$ and $\mathrm{ROS}$, the morphology of the $\mathrm{NCP}_{\mathrm{Cd}}$ was transformed from nanorods to hexagon particles, then broken into nano-fragments. Meanwhile, the fluorescence of $\mathrm{NCP}_{\mathrm{Cd}}$ (at $421 \mathrm{~nm}$ ) was quenched accordingly. For designing the highly sensitive probe for ROS, Rhodamine $6 \mathrm{G}(\mathrm{R} 6 \mathrm{G})$ was doped in $\mathrm{NCP}_{\mathrm{Cd}}$. In the presence of ROS, the fluorescence of $\mathrm{NCP}_{\mathrm{Cd}}$ moiety at $421 \mathrm{~nm}$ was quenched, but the R6G moiety was released from the broken nanorods and the fluorescence at $555 \mathrm{~nm}$ from R6G moiety was recovered. The $\mathrm{R} 6 \mathrm{G}$ doped $\mathrm{NCP}_{\mathrm{Cd}}\left(\mathrm{NCP}_{\mathrm{Cd}}-\mathrm{R}\right)$ can be used as a highly sensitive and selective probe for hydrogen peroxide $\left(\mathrm{H}_{2} \mathrm{O}_{2}\right)$ with detection limit of $12.4 \mathrm{nM}$. Moreover, the $\mathrm{NCP}_{\mathrm{Cd}}-\mathrm{R}$ was further extended to the glucose sensing combined with glucose oxidase (GOx) to oxidate glucose and generate $\mathrm{H}_{2} \mathrm{O}_{2}$, demonstrating the potential for practical applications.
\end{abstract}

Keywords Coordination polymers, reactive oxygen species (ROS), disulfide carboxylate ligand, fluorescent detection, sensitive detection

(Received June 23, 2018; Accepted August 14, 2018; Advance Publication Released Online by J-STAGE August 24, 2018)

\section{Introduction}

Reactive oxygen species (ROS), such as hydrogen peroxide $\left(\mathrm{H}_{2} \mathrm{O}_{2}\right)$, superoxide $\left(\mathrm{O}_{2}{ }^{--}\right)$, hydroxyl radical $(\cdot \mathrm{OH})$ and singlet oxygen $\left({ }^{1} \mathrm{O}_{2}\right)$, play important roles in health and disease related processes. ${ }^{1-4}$ The ROS are produced endogenously through the mitochondrial respiration process, or exogenously by exposure to deleterious conditions including infectious agents and UV light. ${ }^{5,6}$ The excessive production of ROS usually results in diseases (e.g., cancer, arthritis, arteriosclerosis). Moreover, the presence of ROS in atmospheric aerosols can also cause to oxidative stress in the human lung. ${ }^{7,8}$ In the past decades, great efforts have been devoted to detect ROS for understanding the biological roles and the molecular mechanisms of these ROS.9,10 Due to the very low concentration (nanomolar or picomolar) of ROS in biological and environmental systems, high sensitivity is generally required during ROS detection.

Probes based on nanomaterials have been used effectively for detecting ROS owing to their high sensitivity, good solubility and facile surface functionalization for specific targeting. ${ }^{11-13}$ Among them, the nanoscale coordination polymers (NCPs), constructed from metal connectors and bridging ligands, have shown their advantages as sensors, which include their structural and chemical diversity, tunable chemical compositions and

Y.-B. H. and D. Y. contributed equally to this work.

$\dagger$ To whom correspondence should be addressed.

E-mail: songwenjun@tjcu.edu.cn (W.-J. S.); wanghuai1234@ gmail.com (H.-S. W.). biodegradability. ${ }^{14-16}$

Herein, we designed and prepared a type of NCP for sensitive detection of ROS employing $\mathrm{Cd}^{2+}$ as metal center, disulfide carboxylate derivative $\left(2,2^{\prime}\right.$-dithiodibenzoic acid, dtba) as ligand and 1,10-phenanthroline (phen) as co-ligand. As shown in Fig. 1, the fluorescence of the prepared nanoprobe $\left(\mathrm{NCP}_{\mathrm{Cd}}\right)$ can be quenched by ROS. In the presence of ROS, the morphology of the $\mathrm{NCP}_{\mathrm{Cd}}$ was changed from nanorods to hexagon particles accompanied by the decrease of the fluorescence intensity. Then, the hexagon particles were further broken into nanofragments due to the oxidation of ROS, and the fluorescence intensity of the nanoprobe was further quenched. We found the thiol-compounds, such as glutathione (GSH) and cysteine (Cys), can also quench the fluorescence of $\mathrm{NCP}_{\mathrm{Cd}}$, while the morphology of the $\mathrm{NCP}_{\mathrm{Cd}}$ was not transformed from nanorods to the final nano-fragments. We suppose the transformation of the morphology of the $\mathrm{NCP}_{\mathrm{Cd}}$ was due to the breaking of the disulfide bond caused by the oxidation of ROS. ${ }^{17,18}$ Furthermore, the Rhodamine $6 \mathrm{G}(\mathrm{R} 6 \mathrm{G})$ doped $\mathrm{NCP}_{\mathrm{Cd}}\left(\mathrm{NCP}_{\mathrm{Cd}} \mathrm{R}\right)$ exhibits good sensing ability toward ROS. Without ROS, the emission at $421 \mathrm{~nm}$ from $\mathrm{NCP}_{\mathrm{Cd}}$ moiety can be observed, but the emission at $555 \mathrm{~nm}$ from R6G moiety was quenched. In the presence of ROS, the fluorescence of $\mathrm{NCP}_{\mathrm{Cd}}$ moiety at $421 \mathrm{~nm}$ was quenched, but the R6G moiety was released from the broken $\mathrm{NCP}_{\mathrm{Cd}} \mathrm{R}$ and the fluorescence at $555 \mathrm{~nm}$ of $\mathrm{R} 6 \mathrm{G}$ moiety was recovered. The $\mathrm{NCP}_{\mathrm{Cd}}-\mathrm{R}$ shows high selectivity and sensitivity toward ROS, and can be used as a potential ROS probe. 


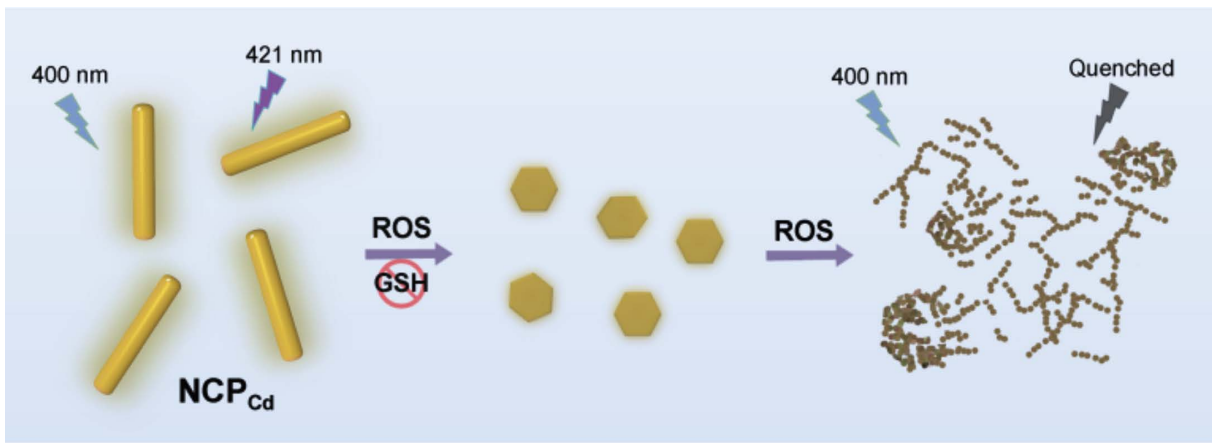

Fig. 1 Schematic illustration of fluorescent coordination polymers based on disulfide carboxylate ligand for ROS sensing.
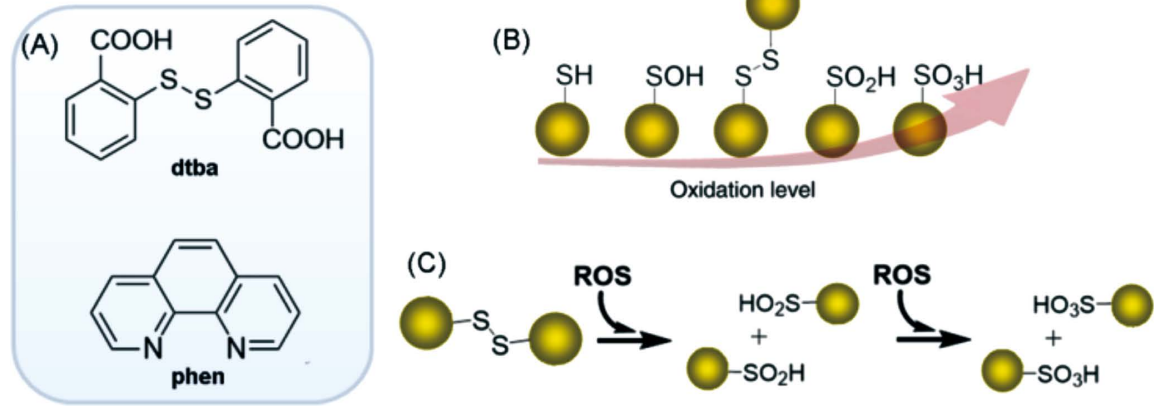

Fig. 2 Schematic overview of redox-based disulfide modification. (A) The structures of ligand dtba and co-ligand for $\mathrm{NCP}_{\mathrm{Cd}}$. (B) The disulfide redox species and their interrelationship. (C) The reaction of disulfide with ROS.

\section{Experimental}

\section{Reagents and materials}

$\mathrm{CdSO}_{4} \cdot 8 \mathrm{H}_{2} \mathrm{O}(98 \%), 2,2^{\prime}$-dithiodibenzoic acid (96\%, dtba), 1,10-phenanthroline (96\%, phen), glutathione (GSH) and cysteine (Cys) were purchased from Alfa Aesar. Rhodamine 6G (95\%, R6G) and glucose oxidase (GOx) were purchased from Sigma-Aldrich (USA). Hydrogen peroxide $\left(\mathrm{H}_{2} \mathrm{O}_{2}, 30 \%\right)$ and glucose were purchased from Nanjing Chemical Reagent Co., Ltd. (Nanjing, China). All aqueous solutions were prepared from deionized water $\left(18 \mathrm{M} \mathrm{cm}^{-1}\right.$, PURELAB Classic, PALL, USA). Unless otherwise stated, all chemical materials were purchased from commercial sources and used without further purification.

\section{Apparatus and measurements}

The morphology of the NCPs was characterized by transmission electron microscopy (TEM, JEM-200CX, Japan). $\mathrm{X}$-ray diffraction patterns were obtained on an X-ray powder diffractometer (XRD, X'TRA, $\mathrm{Cu} K \alpha$ radiation, Switzerland). Fourier transform infrared (FTIR) spectra were collected on a Nicolet 6700 FTIR spectrometer (Thermo Scientific, USA). Fluorescence spectra were recorded on a RF-5301PC spectrophotometer (Shimadzu, Japan).

\section{Synthesis of $N C P_{C d}$}

The mixture of dtba $(0.0926 \mathrm{~g}, 0.3 \mathrm{mmol})$, phen $(0.0198 \mathrm{~g}$, $0.1 \mathrm{mmol})$ and $3 \mathrm{CdSO}_{4} \cdot 8 \mathrm{H}_{2} \mathrm{O}(0.0770 \mathrm{~g}, 0.1 \mathrm{mmol})$ was added into $10 \mathrm{~mL} \mathrm{NaOH}$ solution $(0.1 \mathrm{mM})$, and sealed in a $30-\mathrm{mL}$ vial. The mixture was reacted at $160^{\circ} \mathrm{C}$ for $30 \mathrm{~h}$. The product $\left(\mathrm{NCP}_{\mathrm{Cd}}\right)$ was washed with water and ethanol three times each.

Synthesis of $N C P_{C d}-R$

The mixture of R6G $(0.0100 \mathrm{~g}, 0.02 \mathrm{mmol})$, dtba $(0.1852 \mathrm{~g}$, $0.6 \mathrm{mmol})$, phen $(0.0396 \mathrm{~g}, 0.2 \mathrm{mmol})$ and $3 \mathrm{CdSO}_{4} \cdot 8 \mathrm{H}_{2} \mathrm{O}$ $(0.1540 \mathrm{~g}, 0.2 \mathrm{mmol})$ was added into $25 \mathrm{~mL} \mathrm{NaOH}$ solution $(0.1 \mathrm{mM})$, and sealed in a $30-\mathrm{mL}$ vial. The mixture was reacted at $160^{\circ} \mathrm{C}$ for $30 \mathrm{~h}$. The product $\left(\mathrm{NCP}_{\mathrm{Cd}}-\mathrm{R}\right)$ was washed with water and ethanol three times each.

\section{Fluorescent ROS sensing}

In a typical measurement, $\mathrm{NCP}_{\mathrm{Cd}}$ (or $\left.\mathrm{NCP}_{\mathrm{Cd}}-\mathrm{R}, \sim 10 \mu \mathrm{g} \mathrm{mL}^{-1}\right)$ was suspended in $10 \mathrm{mM}$ PBS buffer ( $\mathrm{pH} 7.4)$, then $\mathrm{H}_{2} \mathrm{O}_{2}$ with different concentrations (from $1 \mathrm{nM}$ to $1 \mu \mathrm{M}$ ) was added into the $\mathrm{NCP}_{\mathrm{Cd}}$ suspension. After allowing the mixture to react for $6 \mathrm{~min}$ at room temperature, the fluorescence spectra of the mixture were detected.

\section{Fluorescent glucose sensing}

Briefly, $\mathrm{NCP}_{\mathrm{Cd}} \mathrm{R}\left(\sim 10 \mu \mathrm{g} \mathrm{mL} \mathrm{m}^{-1}\right)$ was suspended in $10 \mathrm{mM}$ PBS buffer (pH 6.8) containing $50 \mu \mathrm{g} \mathrm{mL}^{-1}$ GOx. Then, different concentrations of glucose were incubated with the mixture at $37^{\circ} \mathrm{C}$ for $30 \mathrm{~min}$. The fluorescence intensities of the reaction solution were measured.

\section{Results and Discussion}

The $\mathrm{NCP}_{\mathrm{Cd}}$ nanorods were successfully synthesized by 

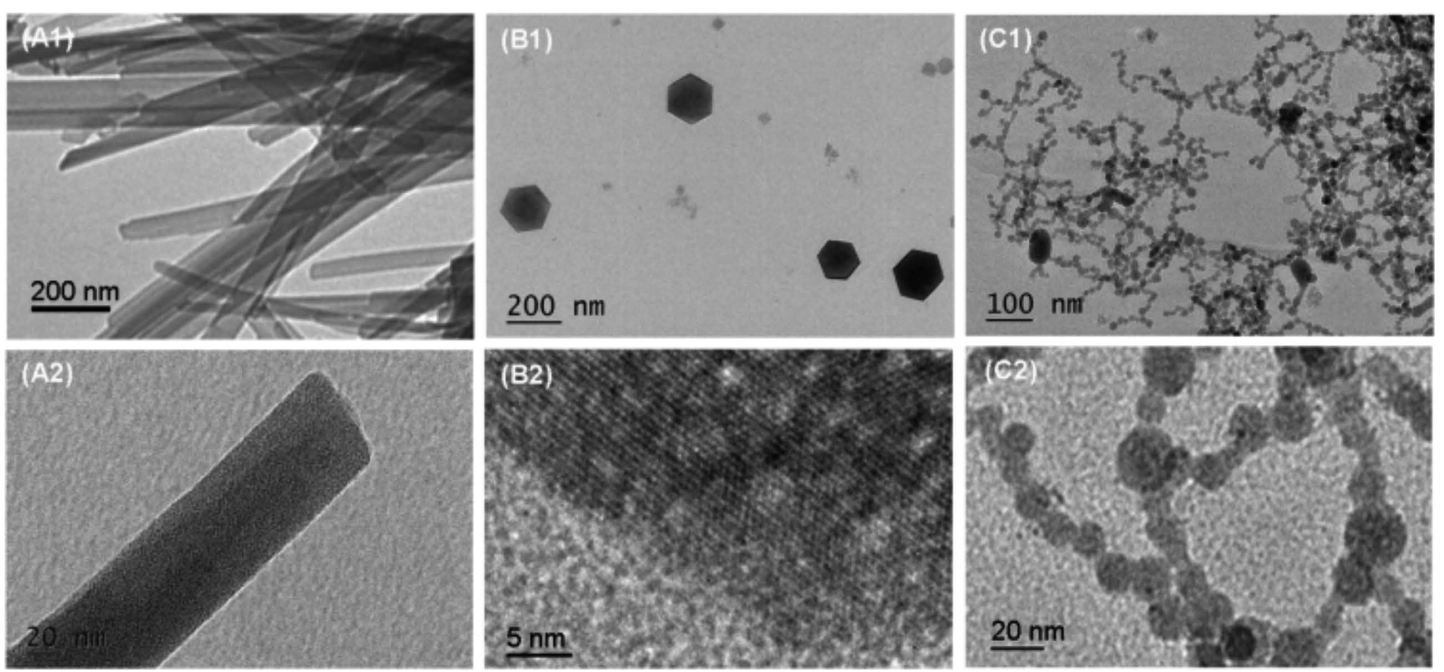

Fig. 3 The morphology of the $\mathrm{NCP}_{\mathrm{Cd}}$ before and after reacting with $\mathrm{ROS}\left(\mathrm{H}_{2} \mathrm{O}_{2}\right)$. (A1 and A2) The $\mathrm{NCP}_{\mathrm{Cd}}$ nanorods. (B1 and $\left.\mathrm{B} 2\right)$ The $\mathrm{NCP}_{\mathrm{Cd}}$ after reacting with $\mathrm{H}_{2} \mathrm{O}_{2}(100 \mathrm{nM}) .(\mathrm{C} 1$ and $\mathrm{C} 2)$ The $\mathrm{NCP}_{\mathrm{Cd}}$ after reacting with $\mathrm{H}_{2} \mathrm{O}_{2}(1 \mu \mathrm{M})$.

hydrothermal method by using dtba as ligand and phen as coligand (Fig. 2A). The dtba contains a disulfide (-S-S-) moiety, which can be oxidized by ROS and converted to sulfinic acid $\left(-\mathrm{SO}_{2} \mathrm{H}\right)$ or sulfonic acid $\left(-\mathrm{SO}_{3} \mathrm{H}\right)$, and also can be reduced by thiol-reducing agents (Fig. 2B). ${ }^{18-20}$ Therefore, in the presence of ROS, the disulfide groups in $\mathrm{NCP}_{\mathrm{Cd}}$ nanorods can be cracked (Fig. 2C) and the morphology of the $\mathrm{NCP}_{\mathrm{Cd}}$ was transformed from nanorods to the final nano-fragments.

The morphology of the $\mathrm{NCP}_{\mathrm{Cd}}$ was characterized by transmission electron microscopy (TEM) (Figs. 3A1 and 3A2). Before the reaction with ROS, the morphology of the $\mathrm{NCP}_{\mathrm{Cd}}$ was nanorods. The powder X-ray diffraction (PXRD) study reveals that the $\mathrm{NCP}_{\mathrm{Cd}}$ was not well crystallized (Fig. S1, Supporting Information). After the $\mathrm{NCP}_{\mathrm{Cd}}$ nanorods reacted with $\mathrm{H}_{2} \mathrm{O}_{2}$, an interesting change of the morphology of the $\mathrm{NCP}_{\mathrm{Cd}}$ occurred. In the presence of a low concentration of $\mathrm{H}_{2} \mathrm{O}_{2}$ $(100 \mathrm{nM})$, the nanorods were changed to hexagon particles with diameter of $100-200 \mathrm{~nm}$ (Fig. 3B1). Figure 3B2 shows that the hexagon particles were in a crystalline state, monitored by high-resolution TEM. However, the structure of the hexagon particles was hard to confirm, because the $-\mathrm{SO}_{2} \mathrm{H}$ or $-\mathrm{SO}_{3} \mathrm{H}$ generated from the reaction between $\mathrm{H}_{2} \mathrm{O}_{2}$ and disulfide, and the particle size was too small for single-crystal $\mathrm{X}$-ray diffraction. Moreover, if more $\mathrm{H}_{2} \mathrm{O}_{2}$ was presented, the hexagon particles further reacted with $\mathrm{H}_{2} \mathrm{O}_{2}$ and broke into nano-fragments (Figs. 3C1 and 3C2). Figure S2 shows the morphology changes during the reaction between hexagon particles and $\mathrm{H}_{2} \mathrm{O}_{2}$ with different concentrations from $100 \mathrm{nM}$ to $1 \mu \mathrm{M}$. We suppose the morphology change was due to the cleavage of -S-S- after oxidization by $\mathrm{H}_{2} \mathrm{O}_{2}$. FT-IR spectra confirmed the reaction between disulfide and $\mathrm{H}_{2} \mathrm{O}_{2}$. As shown in Fig. S3 (Supporting Information), the peak intensity of $v_{(\mathrm{S}-\mathrm{S})}$ around $852 \mathrm{~cm}^{-1}$ was decreased, while the peak intensity of $v_{(\mathrm{S}=\mathrm{O})}$ around $910 \mathrm{~cm}^{-1}$ was increased. Furthermore, the generation of the peak $v_{(\mathrm{OH})}$ located around $3330 \mathrm{~cm}^{-1}$ indicated the existence of $-\mathrm{SO}_{2} \mathrm{H}$ or $-\mathrm{SO}_{3} \mathrm{H}$ in $\mathrm{NCP}_{\mathrm{Cd}}$ after reacting with $\mathrm{H}_{2} \mathrm{O}_{2}{ }^{21,22}$

The fluorescence property of $\mathrm{NCP}_{\mathrm{Cd}}$ nanorods was investigated in PBS buffer ( $\mathrm{pH} 7.4$ ) at room temperature. Figure 4A shows the excitation and emission spectra of the $\mathrm{NCP}_{\mathrm{Cd}}$ nanorods. The $\mathrm{NCP}_{\mathrm{Cd}}$ displays an emission peak at $421 \mathrm{~nm}$ with the excitation at $400 \mathrm{~nm}$ that can be attributed to the intra-ligand $\pi^{*}-\pi$ transitions. ${ }^{16}$ Among the ROS, $\mathrm{H}_{2} \mathrm{O}_{2}$ is relatively stable and was thus selected as the analyte for investigating the ROS sensing ability of $\mathrm{NCP}_{\mathrm{Cd}}$. The $\mathrm{NCP}_{\mathrm{Cd}}$ can quickly react with $\mathrm{H}_{2} \mathrm{O}_{2}$ within $10 \mathrm{~min}$ and the emission peak at $421 \mathrm{~nm}$ was accordingly quenched (Fig. 4B). Various concentrations of $\mathrm{H}_{2} \mathrm{O}_{2}$ (from $5 \mathrm{nM}$ to $1000 \mathrm{nM}$ ) were investigated to interact with $\mathrm{NCP}_{\mathrm{Cd}}$ (Fig. 4C). A plot of the fluorescence quenching intensity $\left(I_{0}\right.$ is the fluorescence intensity of $\mathrm{NCP}_{\mathrm{Cd}}$ at the beginning of the reaction with $\mathrm{H}_{2} \mathrm{O}_{2} ; I$ is the fluorescence intensity of $\mathrm{NCP}_{\mathrm{Cd}}$ after reacting with $\mathrm{H}_{2} \mathrm{O}_{2}$ ) as a function of the $\mathrm{H}_{2} \mathrm{O}_{2}$ concentration gives a linear calibration curve from 50 to $120 \mathrm{nM}$ (Fig. 4D).

Furthermore, we found the thiol-compounds can also quench the fluorescence of $\mathrm{NCP}_{\mathrm{Cd}}$. But, the morphology of the $\mathrm{NCP}_{\mathrm{Cd}}$ was not transformed from nanorods to hexagon particles or nano-fragments, which can be induced by ROS (Fig. S4, Supporting Information). It might because the thiol-compounds tend to be adsorbed on the surface of $\mathrm{NCP}_{\mathrm{Cd}}$ nanorods, where there are $\mathrm{Cd}^{2+}$ ions not fully coordinated. Therefore, there is little chance for thiol-compounds to reduce the disulfide and break the $\mathrm{NCP}_{\mathrm{Cd}}$ nanorods.

For developing a fluorescent probe with high selectivity towards ROS, the R6G doped $\mathrm{NCP}_{\mathrm{Cd}}\left(\mathrm{NCP}_{\mathrm{Cd}}-\mathrm{R}\right)$ was prepared by one-pot synthesis. Figure S5 (Supporting Information) gives the bright-field photographs of $\mathrm{NCP}_{\mathrm{Cd}} \mathrm{R}$ and $\mathrm{NCP}_{\mathrm{Cd}}$. The color of $\mathrm{NCP}_{\mathrm{Cd}} \mathrm{R}$ was pink because of the doped R6G, while the $\mathrm{NCP}_{\mathrm{Cd}}$ was white powder. In the $\mathrm{NCP}_{\mathrm{Cd}}-\mathrm{R}$, the fluorescence intensity of R6G (at $555 \mathrm{~nm}$ ) was quenched because the metal cations $\left(\mathrm{Cd}^{2+}\right)$ of NCPs have intrinsic fluorescence quenching ability. ${ }^{23-25}$ However, the fluorescence of $\mathrm{NCP}_{\mathrm{Cd}}-\mathrm{R}$ at $421 \mathrm{~nm}$ was not affected by the doped R6G (Fig. 5A). Furthermore, photobleaching experiments for $\mathrm{NCP}_{\mathrm{Cd}}-\mathrm{R}$ and $\mathrm{NCP}_{\mathrm{Cd}}$ were investigated. According to Fig. S6, the fluorescence intensities of $\mathrm{NCP}_{\mathrm{Cd}} \mathrm{R}$ and $\mathrm{NCP}_{\mathrm{Cd}}$ at $421 \mathrm{~nm}$ decrease slowly with UV irradiation within $60 \mathrm{~min}$. This indicates that the $\mathrm{NCP}_{\mathrm{Cd}}-\mathrm{R}$ and $\mathrm{NCP}_{\mathrm{Cd}}$ are suitable as fluorescent probes for long-time observations.

The morphology of $\mathrm{NCP}_{\mathrm{Cd}}-\mathrm{R}$ was also nanorod similar as $\mathrm{NCP}_{\mathrm{Cd}}$ (Fig. 5B1). The $\mathrm{NCP}_{\mathrm{Cd}}-\mathrm{R}$ nanorods with shorter length can be obtained simply by ultrasonication (Fig. 5B2). These 
(A)
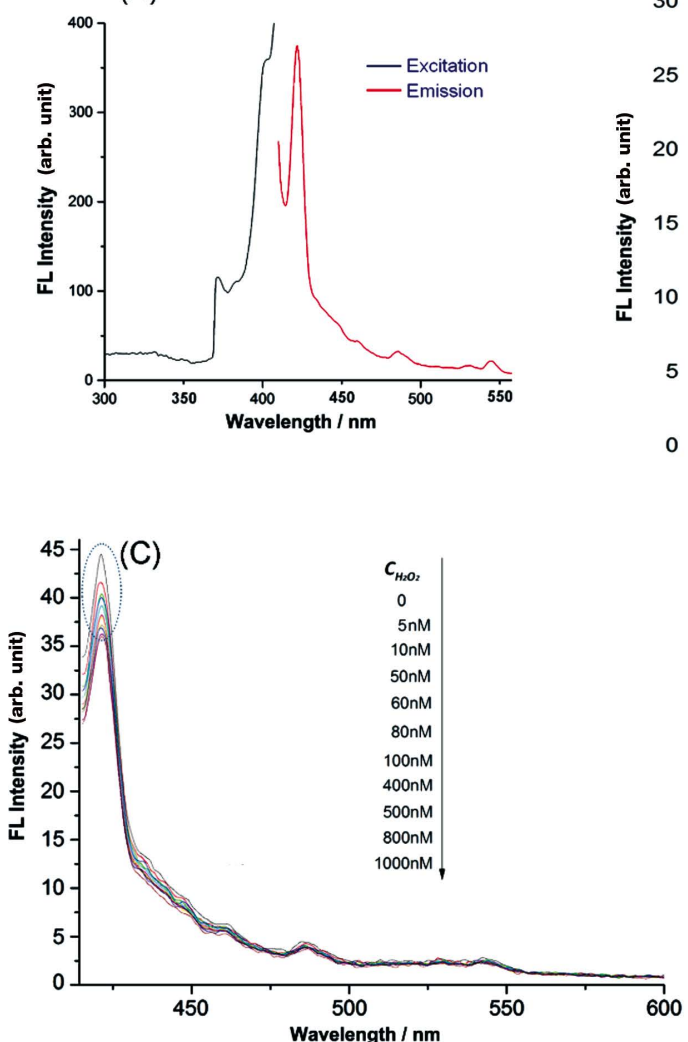
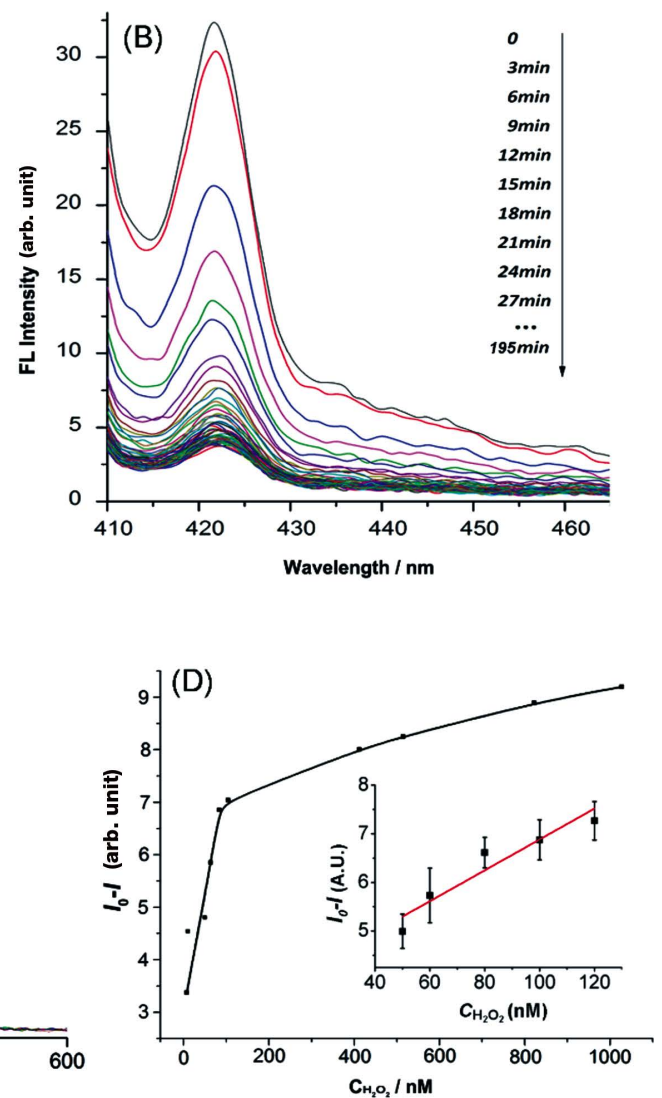

Fig. 4 Fluorescence property of $\mathrm{NCP}_{\mathrm{Cd}}$. (A) Excitation and emission spectra of the $\mathrm{NCP}_{\mathrm{Cd}}$. (B) Fluorescence of the $\mathrm{NCP}_{\mathrm{Cd}}\left(\sim 10 \mu \mathrm{g} \mathrm{mL}-1\right.$ in PBS, pH 7.4) quenched by $\mathrm{H}_{2} \mathrm{O}_{2}(1 \mu \mathrm{M}$, freshly diluted from $30 \% \mathrm{H}_{2} \mathrm{O}_{2}$ before experiment) with different reaction time. (C) Fluorescence of the $\mathrm{NCP}_{\mathrm{Cd}}$ $\left(\sim 10 \mu \mathrm{g} \mathrm{mL}^{-1}\right.$ in PBS, $\left.\mathrm{pH} 7.4\right)$ quenched by $\mathrm{H}_{2} \mathrm{O}_{2}$ with different concentrations (the reaction time was $6 \mathrm{~min})$. (D) Plot of the fluorescence intensity $\left(I_{0}-I\right)$ of $\mathrm{NCP}_{\mathrm{Cd}}$ at $421 \mathrm{~nm}$ as a function of the concentration of $\mathrm{H}_{2} \mathrm{O}_{2}(5-1000 \mathrm{nM})$. Inset: linear correlation between the fluorescence quenching intensity and $\mathrm{H}_{2} \mathrm{O}_{2}$ concentration $(10-120 \mathrm{nM})$. Error bars indicate s.d. $(n=3)$.

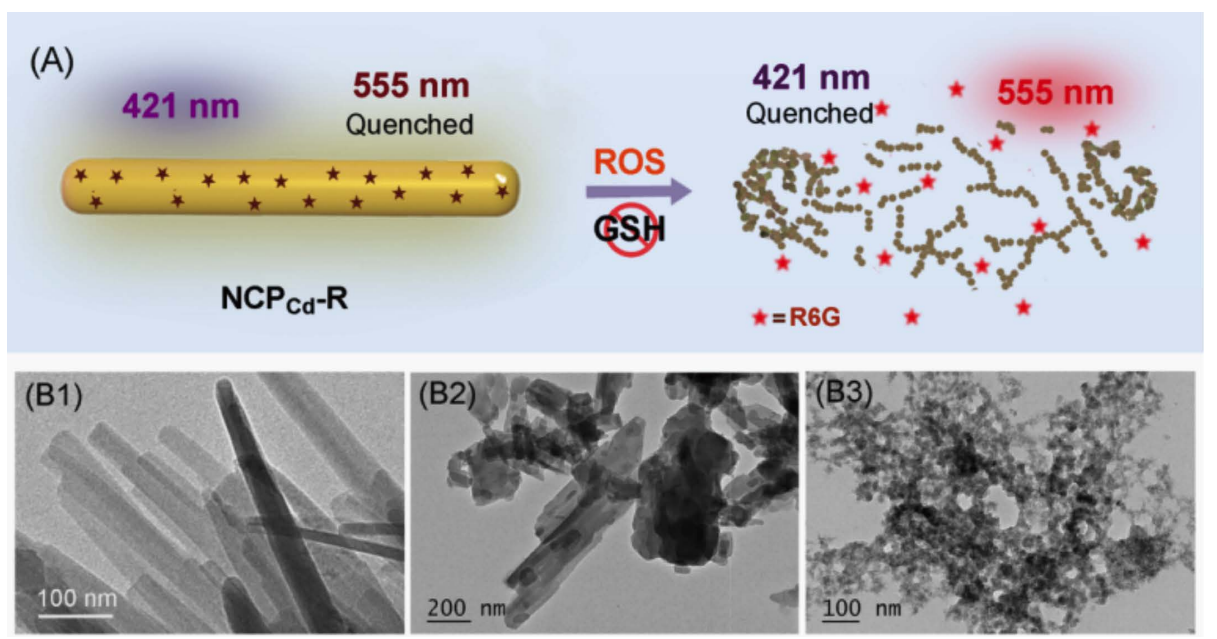

Fig. $5 \quad \mathrm{NCP}_{\mathrm{Cd}}-\mathrm{R}$ for ROS sensing. (A) Schematic illustration of ROS sensing by $\mathrm{NCP}_{\mathrm{Cd}}-\mathrm{R}$. (B) TEM images including: (B1) the morphology of $\mathrm{NCP}_{\mathrm{Cd}}-\mathrm{R}$; (B2) the morphology of $\mathrm{NCP}_{\mathrm{Cd}}-\mathrm{R}$ broken by ultrasonication; (B3) the morphology of $\mathrm{NCP}_{\mathrm{Cd}}-\mathrm{R}$ after reacting with $\mathrm{H}_{2} \mathrm{O}_{2}(1 \mu \mathrm{M})$.

small nanorods were well dispersed in PBS buffer ( $\mathrm{pH} 7.4$ ). After reacting with $\mathrm{H}_{2} \mathrm{O}_{2}$, the nanorods were broken into nanofragments (Fig. 5B3). Meanwhile, the emission peak at $421 \mathrm{~nm}$ was quenched, and the R6G was released followed by the increase of the emission peak at $555 \mathrm{~nm}$ (Fig. 6A). The $\mathrm{NCP}_{\mathrm{Cd}}-\mathrm{R}$ shows good selectivity for ROS. As shown in Fig. 6B, 

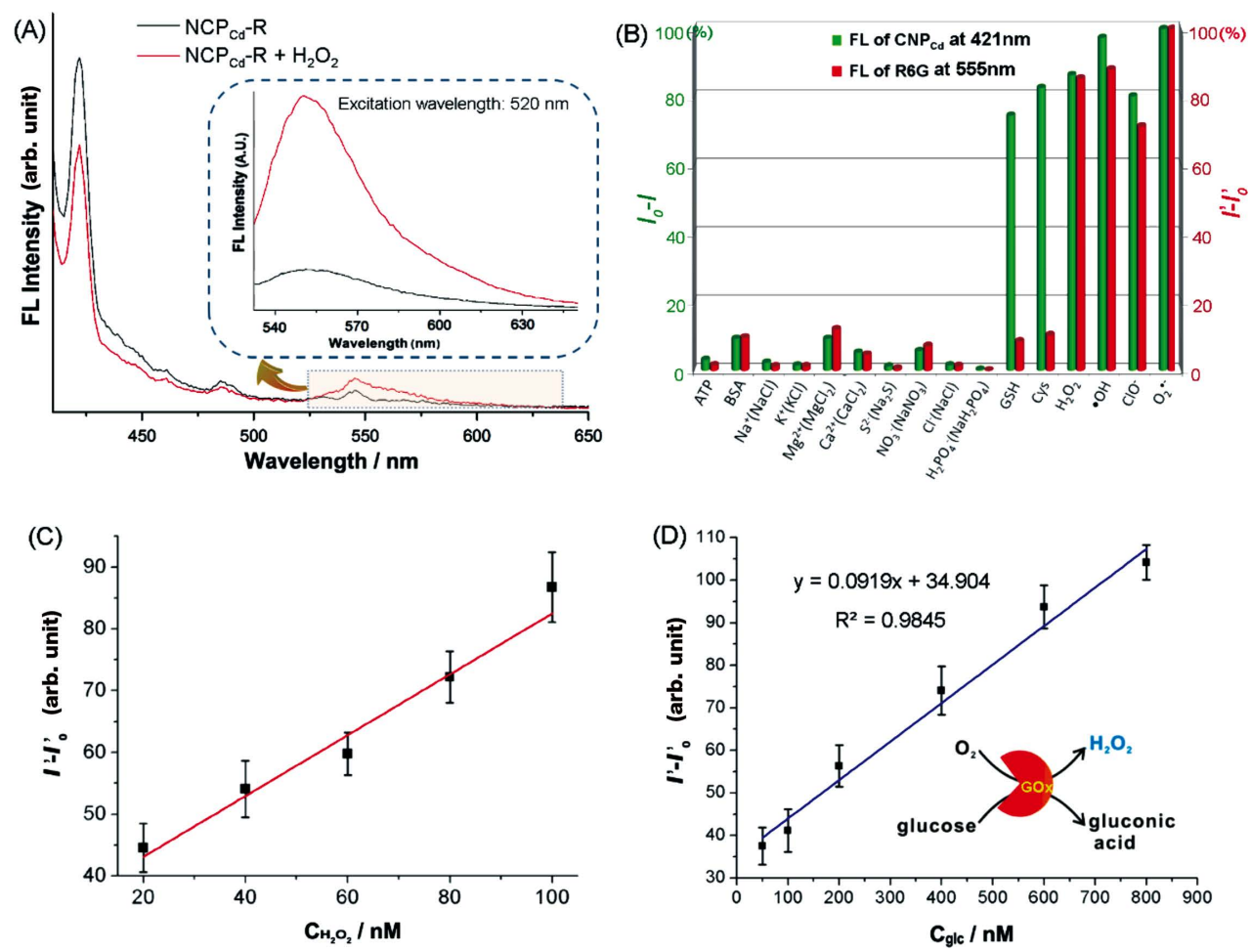

Fig. 6 ROS sensing by $\mathrm{NCP}_{\mathrm{Cd}}-\mathrm{R}$. (A) Fluorescence of the $\mathrm{NCP}_{\mathrm{Cd}}-\mathrm{R}(\sim 10 \mu \mathrm{g} \mathrm{mL}-1$ in $\mathrm{PBS}, \mathrm{pH} 7.4)$ before and after reacting with $\mathrm{H}_{2} \mathrm{O}_{2}(1 \mu \mathrm{M})$. The emission peak at $421 \mathrm{~nm}$ was excited by $400 \mathrm{~nm}$ and the emission peak at $555 \mathrm{~nm}$ was excited by $520 \mathrm{~nm}$. (B) Relative fluorescence intensity observed upon reaction of $\mathrm{NCP}_{\mathrm{Cd}} \mathrm{R}$ with ROS, thiol-compounds and other anions (or biomolecules) $)^{26}(1 \mu \mathrm{M})$. (C and D) Plot of the fluorescence intensity $\left(I_{\mathrm{R} 6 \mathrm{G}}^{\prime}-I_{0, \mathrm{RGG}}^{\prime}\right)$ of $\mathrm{NCP}_{\mathrm{Cd}}-\mathrm{R}$ at $555 \mathrm{~nm}$ as a function of the concentration of $\mathrm{H}_{2} \mathrm{O}_{2}(20-100 \mathrm{nM})(\mathrm{C})$ and glucose (glc, $\left.50-800 \mathrm{nM}\right)$ (D). Error bars indicate s.d. $(n=3)$.

Table 1 Comparison of $\mathrm{NCP}_{\mathrm{Cd}}-\mathrm{R}$ nanorods with some of the recently reported nano-sensors for $\mathrm{ROS}\left(\mathrm{H}_{2} \mathrm{O}_{2}\right)$ sensing

\begin{tabular}{|c|c|c|c|c|}
\hline Name & Nanomaterial supporter & Ratiometric sensing & Detection limit & Reference \\
\hline $\mathrm{NCP}_{\mathrm{Cd}}-\mathrm{R}$ & Coordination polymer & No & $12.4 \mathrm{nM}$ & This work \\
\hline FNFM & Gold nanocluster & No & $500 \mathrm{nM}$ & 27 \\
\hline $\mathrm{Fc} @ \mathrm{MSN}-\mathrm{F}_{\mathrm{DNA}} / \mathrm{PTAD}$ & Silica nanoparticle & No & $2.4 \mathrm{nM}$ & 28 \\
\hline CNWD & $\mathrm{CeO}_{2}$ nanowire & No & $0.64 \mu \mathrm{M}$ & 29 \\
\hline CYD1-UCNPs & Upconverting nanoparticle & Yes & $80 \mathrm{nM}$ & 30 \\
\hline $\mathrm{MnO}_{2}$-modified UCNPs & $\mathrm{MnO}_{2}$ nanosheet, and upconversion nanoparticle & No & $0.9 \mu \mathrm{M}$ & 31 \\
\hline PMT-F127 micelle & Polymeric micelle & Yes & $0.95 \mu \mathrm{M}$ & 32 \\
\hline CuNCs & $\mathrm{Cu}$ nanocluster & No & $0.2 \mu \mathrm{M}$ & 33 \\
\hline Single plasmonic nanoprobe & Single Au nanoparticle & No & $10 \mu \mathrm{M}$ & 34 \\
\hline $\mathrm{Eu}(\mathrm{III})$-doped $\mathrm{GdVO}_{4}$ nanoparticles & $\mathrm{GdVO}_{4}$ nanocrystal & No & $1.6 \mu \mathrm{M}$ & 35 \\
\hline
\end{tabular}

the fluorescence of $\mathrm{NCP}_{\mathrm{Cd}}-\mathrm{R}$ detected at 421 and $555 \mathrm{~nm}$ can be selectively quenched or recovered in the presence of $\mathrm{H}_{2} \mathrm{O}_{2}$. Even the thiol-compounds (such as GSH and Cys) can quench the emission peak at $421 \mathrm{~nm}$, but these compounds cannot lead to the recovery of the emission peak at $555 \mathrm{~nm}$. It is because the thiol-compounds cannot break the $\mathrm{NCP}_{\mathrm{Cd}}-\mathrm{R}$ nanorods into nano-fragments and the R6G cannot release from the $\mathrm{NCP}_{\mathrm{Cd}}-\mathrm{R}$. Therefore, the $\mathrm{NCP}_{\mathrm{Cd}}-\mathrm{R}$ can be used as a fluorescent probe for selectively sensing ROS. According to the fluorescence intensity of R6G, a good linear relationship for ROS (including $\mathrm{H}_{2} \mathrm{O}_{2}$, $\cdot \mathrm{OH}, \mathrm{ClO}^{--}$, and $\mathrm{O}_{2}{ }^{-}$) can be obtained (Fig. 6C and Fig. S7). The detection limit for $\mathrm{H}_{2} \mathrm{O}_{2}$ (prepared by diluting $30 \% \mathrm{H}_{2} \mathrm{O}_{2}$ directly) was $12.4 \mathrm{nM}$, calculated according to $3 S_{0} / S$, where $S_{0}$ is the standard deviation of the blank $(n=11)$ and $S$ is the slope of the calibration curve. As a demonstration, the $\mathrm{NCP}_{\mathrm{Cd}}-\mathrm{R}$ shows good $\mathrm{H}_{2} \mathrm{O}_{2}$ detecting ability compared with the recently reported nano-sensors (including single $\mathrm{Au}$ nanoparticle, upconversion nanoparticles, polymeric nanoprobes, etc.) (Table 1).

The sensitive response of $\mathrm{NCP}_{\mathrm{Cd}}-\mathrm{R}$ toward $\mathrm{H}_{2} \mathrm{O}_{2}$ provides a potential platform to detect substrates involving $\mathrm{H}_{2} \mathrm{O}_{2}$-generation reactions for biological applications. For example, the GOx can specifically catalyze the oxidation of glucose in the presence of oxygen to form $\mathrm{H}_{2} \mathrm{O}_{2}{ }^{36}$ Herein, as a proof-of-concept demonstration, glucose was chosen as the model detective sample. Because of the high substrate specificity of GOx, $\mathrm{H}_{2} \mathrm{O}_{2}$ can be generated after the addition of glucose to the $\mathrm{NCP}_{\mathrm{Cd}}-\mathrm{R}$ suspension containing GOx. Then, the fluorescence intensity of 
R6G was increased due to the reaction of $\mathrm{H}_{2} \mathrm{O}_{2}$ and $\mathrm{NCP}_{\mathrm{Cd}}-\mathrm{R}$. As shown in Fig. $6 \mathrm{D}$, good linear relationship of $\left(I_{\mathrm{R} 6 \mathrm{G}}^{\prime}-I_{0, \mathrm{R} 6 \mathrm{G}}^{\prime}\right)$ (where $I^{\prime}$ and $I_{0}^{\prime}$ are the peak fluorescence intensities in the presence and absence of the target, respectively) versus glucose was obtained in a range of $50-800 \mathrm{nM}$. Therefore, the $\mathrm{NCP}_{\mathrm{Cd}}-\mathrm{R}$ can be potentially used as a glucose biosensor based on the reaction of GOx and glucose.

\section{Conclusions}

In conclusion, a fluorescent coordination polymer $\left(\mathrm{NCP}_{\mathrm{Cd}}-\mathrm{R}\right)$ based on disulfide carboxylate ligand was prepared via one-pot synthesis. The $\mathrm{NCP}_{\mathrm{Cd}}-\mathrm{R}$ nanorods can be broken by ROS, meanwhile the fluorescence of $\mathrm{NCP}_{\mathrm{Cd}}$ moiety (at $421 \mathrm{~nm}$ ) was quenched and the fluorescence of the released R6G moiety (at $555 \mathrm{~nm}$ ) was recovered. Even the thiol-compounds can also quench the fluorescence of $\mathrm{NCP}_{\mathrm{Cd}}$ moiety, but it cannot break the $\mathrm{NCP}_{\mathrm{Cd}}-\mathrm{R}$ nanorods into nano-fragments and $\mathrm{R} 6 \mathrm{G}$ cannot be released. Therefore, the thiol-compounds cannot make the fluorescence of R6G "turn-on". The $\mathrm{NCP}_{\mathrm{Cd}}-\mathrm{R}$ probe shows high selectively and sensitivity towards $\mathrm{H}_{2} \mathrm{O}_{2}$. Furthermore, the $\mathrm{NCP}_{\mathrm{Cd}}-\mathrm{R}$ probe provided an alternative platform as a glucose sensor by detecting $\mathrm{H}_{2} \mathrm{O}_{2}$, which is produced from the GOxcatalyzed oxidation of glucose.

\section{Acknowledgements}

This work was supported by the National Natural Science Foundation of China (21705165), Jiangsu Provincial Natural Science Foundation (No. BK20150689), the Open Project Program of MOE Key Laboratory of Drug Quality Control and Pharmacovigilance (No. DQCP2017MS03), the Tianjin Science and Technology Support Program (No. 18YFZCNC01140).

\section{Supporting Information}

Figures S1 - S7 [PXRD, TEM images, FT-IR spectra of $\mathrm{NCP}_{\mathrm{Cd}}$, and photobleaching experiment]. This material is available free of charge on the Web at http://www.jsac.or.jp/analsci/.

\section{References}

1. M. Nishikawa, Cancer Lett., 2008, 266, 53.

2. K. Brieger, S. Schiavone, F. J. Miller, Jr., and K.-H. Krause, Swiss Med. Weekly, 2012, 142.

3. T. Finkel and N. J. Holbrook, Nature, 2000, 408, 239.

4. K. S. Kasprzak, Free Radical Biol. Med., 2002, 32, 958.

5. X. Wen, J. Wu, F. Wang, B. Liu, C. Huang, and Y. Wei, Free Radical Biol. Med., 2013, 65, 402.

6. S. I. Dikalov and D. G. Harrison, Antioxid. Redox Sign., 2014, 20, 372

7. H.-S. Wang, F.-N. Xiao, Z.-Q. Li, J. Ouyang, Z.-Q. Wu, X.-H. Xia, and G.-J. Zhou, Lab Chip, 2014, 14, 1123.

8. H.-S. Wang, C. Wang, Y.-K. He, F.-N. Xiao, W.-J. Bao, X.-H Xia, and G.-J. Zhou, Anal. Chem., 2014, 86, 3013.

9. R. Matsuoka, C. Kobayashi, A. Nakagawa, S. Aoyagi,
T. Aikawa, T. Kondo, S. Kasai, and M. Yuasa, Anal. Sci., 2017, 33, 911.

10. N. Soh, K. Makihara, T. Ariyoshi, D. Seto, T. Maki, H. Nakajima, K. Nakano, and T. Imato, Anal. Sci., 2008, 24, 293.

11. E. Ju, Z. Liu, Y. Du, Y. Tao, J. Ren, and X. Qu, ACS Nano, 2014, 8, 6014.

12. T. Chen, Y. Hu, Y. Cen, X. Chu, and Y. Lu, J. Am. Chem. Soc., 2013, 135, 11595.

13. S. Wang, N. Li, W. Pan, and B. Tang, Trac-Trend Anal. Chem., 2012, 39, 3.

14. J. Della Rocca, D. Liu, and W. Lin, Acc. Chem. Res., 2011, 44, 957.

15. W. J. Rieter, K. M. Pott, K. M. L. Taylor, and W. Lin, J. Am. Chem. Soc., 2008, 130, 11584.

16. S.-Z. Ge, Q. Liu, S. Deng, Y.-Q. Sun, and Y.-P. Chen, J. Inorg. Organomet. Polym., 2013, 23, 571.

17. P. D. Ray, B.-W. Huang, and Y. Tsuji, Cell Signal., 2012, 24, 981.

18. J.-G. Lee, K. Baek, N. Soetandyo, and Y. Ye, Nat. Commun., 2013, 4, 1568.

19. M. H. Lee, Z. Yang, C. W. Lim, Y. H. Lee, S. Dongbang, C. Kang, and J. S. Kim, Chem. Rev., 2013, 113, 5071.

20. C. E. Paulsen and K. S. Carroll, Chem. Rev., 2013, 113 , 4633.

21. J.-C. Zhong, S.-Z. Ge, F. Wan, Y.-Q. Sun, and Y.-P. Chen, J. Inorg. Organomet. Polym., 2014, 24, 633.

22. W. R. Fawcett and A. A. Kloss, J. Phys. Chem., 1996, 100, 2019.

23. T. Ye, Y. Liu, M. Luo, X. Xiang, X. Ji, G. Zhou, and Z. He, Analyst, 2014, 139, 1721.

24. J. Tian, Q. Liu, J. Shi, J. Hu, A. M. Asiri, X. Sun, and Y. He, Biosens. Bioelectron., 2015, 71, 1.

25. H.-T. Zhang, J.-W. Zhang, G. Huang, Z.-Y. Du, and H.-L. Jiang, Chem. Commun., 2014, 50, 12069.

26. H.-S. Wang, W.-J. Bao, S.-B. Ren, M. Chen, K. Wang, and X.-H. Xia, Anal. Chem., 2015, 87, 6828.

27. A. Senthamizhan, B. Balusamy, Z. Aytac, and T. Uyar, Anal. Bioanal. Chem., 2016, 408, 1347.

28. C. Liu, W. Chen, Z. Qing, J. Zheng, Y. Xiao, S. Yang, L. Wang, Y. Li, and R. Yang, Anal. Chem., 2016, 88, 3998.

29. W. Gao, X. Wei, X. Wang, G. Cui, Z. Liu, and B. Tang, Chem. Commun., 2016, 52, 3643.

30. Y. Zhou, W. Pei, X. Zhang, W. Chen, J. Wu, C. Yao, L. Huang, H. Zhang, W. Huang, J. S. C. Loo, and Q. Zhang, Biomaterials, 2015, 54, 34.

31. J. Yuan, Y. Cen, X.-J. Kong, S. Wu, C.-L. Liu, R.-Q. Yu, and X. Chu, ACS Appl. Mater. Interfaces, 2015, 7, 10548.

32. J. Qiao, Z. Liu, Y. Tian, M. Wu, and Z. Niu, Chem. Commun., 2015, 51, 3641.

33. H. Miao, D. Zhong, Z. Zhou, and X. Yang, Nanoscale, 2015, 7, 19066.

34. Y. Kim, J. Y. Park, H. Y. Kim, M. Lee, J. Yi, and I. Choi, Chem. Commun., 2015, 51, 15370.

35. V. Muhr, M. Buchner, T. Hirsch, D. J. Jovanovic, S. D. Dolic, M. D. Dramicanin, and O. S. Wolfbeis, Sens. Actuators, B, 2017, 241, 349.

36. G. Mao, Q. Cai, F. Wang, C. Luo, X. Ji, and Z. He, Anal. Chem., 2017, 89, 11628. 